\title{
Earth Terraforming
}

\section{Terraformar la Tierra}

\author{
BORTONI-ANZURES, Liborio $\dagger^{*} \&$ ORTIZ-MOCTEZUMA, Manuel Benjamín
}

Universidad Politécnica de Victoria. Departamento de Mecatrónica

ID $1^{\text {st }}$ Author: Liborio, Bortoni-Anzures / ORC ID: 0000-0003-2025-4369, CVU CONACYT ID: 92743

ID $1^{\text {st }}$ Coauthor: Manuel Benjamín, Ortiz-Moctezuma / ORC ID: 0000-0002-7717-5963, CVU CONACYT ID: 202196

DOI: 10.35429/EJROP.2019.8.5.7.12

Received February 13, 2019; Accepted May 30, 2019

\begin{abstract}
The concept of terrafomation is applied in general to establish a course of action in which hypothetically, it is possible to modify the natural conditions of a planet or moon to make it habitable for the human race, create an atmosphere with breathable air, potable water, fertile soils, climatic stability at a comfortable temperature; this process could take hundreds or thousands of years, as well as an important investment of resources and technology, however in the course of the time that we have inhabited this planet has deteriorated in many of its characteristics, to the point that it could be close the day in which the Earth is no longer apt to sustain the life of the human race. This article shows some of the challenges we should face so that the planet can recover its original benefits, as well as adapt our technology to be able to inhabit regions that we consider hostile today. Surely it would require a minor effort to completely transform a distant planet.
\end{abstract}

Ecology, health, Future

\section{Resumen}

El concepto de terrafomación es aplicado en lo general para establecer un curso de acción en el que de manera hipotética, fuera posible modificar las condiciones naturales de un planeta o luna para hacerlo habitable para la raza humana, crear una atmósfera con aíre respirable, agua potable, suelos fértiles, estabilidad climática a una temperatura cómoda; este proceso podría tomar cientos o miles de años, así como una importante inversión de recursos y tecnología, sin embargo en el transcurso del tiempo que hemos habitado este planeta se ha deteriorado en muchas de sus características, al punto de que podría estar cercano el día en que la Tierra ya no sea apta para sostener la vida de la raza humana. En este artículo se muestran algunos de los retos que deberíamos confrontar para que el planeta pueda recuperar sus bondades originales, así como adaptar nuestra tecnología para poder habitar regiones que hoy consideramos hostiles. Seguramente requeriría un esfuerzo mucho menor que transformar por completo un planeta lejano.

\section{Ecología, Salud, Futuro}

Citation: BORTONI-ANZURES, Liborio \& ORTIZ-MOCTEZUMA, Manuel Benjamín. Earth Terraforming. ECORFAN Journal Republic of Paraguay. 2019, 5-8: 7-12.

\footnotetext{
* Correspondence to author (email: lbortoni@ upv.edu.mx)

$\dagger$ Researcher contributing as first author.
} 


\section{Introduction}

It is estimated that our planet is about 15 billion years old, and it took some of those millions of years to be fit to support life, the oldest fossils that have been identified date back 3,500 million years, a large number of different species have arisen, evolved and disappeared in this time, the conditions of the planet are in permanent change, as a result of their cooling and loss in speed of rotation among other factors, as well as factors in their environment, solar radiation, meteors or other phenomena celestial.

The challenge to survive is adaptation. The first being related to our evolutionary history, the first primate on the planet appears 70 million years ago (the Purgatory) from which we progressed to become, 50 thousand years ago, the current Homo Sapiens Sapiens, dominant species, the first inhabitant of our world that is able to modify its environment to adapt it to its whims.

Victims of our own success in modifying the habitat, we proliferate irrationally in densely populated regions, with increasing complications to satisfy the requiremnts for living of its inhabitants. In figure 1, you can see a couple of photos of the planet provided by NASA, one 1978 (left) and another 2012 (right), in them you can clearly see the loss of vegetation, the melting of the north pole, to give rise to a growing desert.

The erosion of resources, the accumulation of pollutants, waste resulting from our activities and the extermination of other species, has reached a point where moving to another world would be a good solution, even if we keep on the same unsustainable way of living.

Finding a planet compatible with our current lifestyle, has not been possible so far. In addition to the efforts, resources and time it would take to carry out the exodus and terraforming, not to mention that we would probably continue with our same practices.
Although we have damaged our house a lot, the planet Earth is much closer to being habitable than someone else could be, if we apply our current knowledge and develop sustainable technology, instead of investing in research to be able to flee, we can modify our actions to diminish the deterioration or even more, contribute to the Earth regaining its balance, and not because we must "save the planet" but so that we can live in it for longer.

\section{Current panorama}

Figures 1 and 2 can be compared photographs of the planet Earth seen from space, provided by NASA, in which 34 years away (1978 2012), the conditions of the region that is appreciated have changed considerably.

It seems evident the reduction of the polar cap (probably due to thaw) and the growth of the desert areas, which in turn could imply a change in the climatic conditions of the planet, affecting the flora and fauna.

\section{Solid waste}

The amount of solid waste is one of the greatest sources of pollution resulting from our current lifestyle, each person discards an average of 1 kilogram of garbage per day, although the economic level of each country is closely related to the waste of each inhabitant, up to $4.5 \mathrm{~kg}$ in the more developed countries, in Mexico, for example, each citizen throws to the dump about $1.7 \mathrm{~kg}$, while other less fortunate countries, a figure less than 300 grams.

What implies that every day more than 2 billion tons of solid waste are generated, according to some analysis, it is considered that $95 \%$ of the total of the things that we buy, reaches the dump in less than 6 months. 


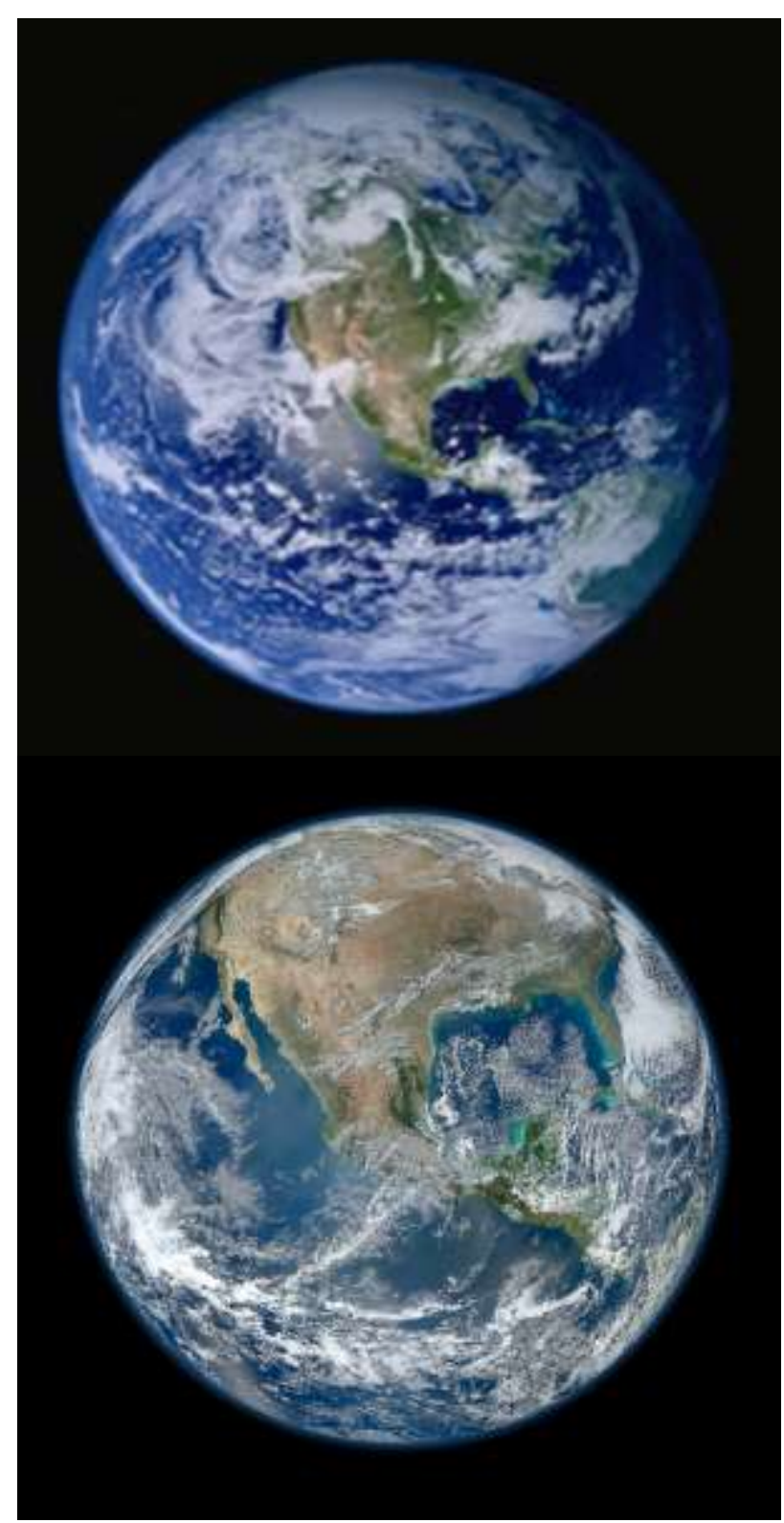

Figure 1 Planet Earth in 1978 (superior) and Figure 2 Earth in 2012 (bottom) Source: NASA

Research carried out by the United Nations in 2017, in the framework of the World Environment Day, indicated that an average of 10 million tons of this garbage is going to hit the sea, according to Antonio Guterres, Secretary General of the UN. Such amount of waste causes the intoxication of marine species that have been brought to extinction and some return to us at our own tables in the form of micro-plastics within the bodies of fish and shellfish that we consume.

Much of the non-biodegradable garbage thrown into the sea is washed away by marine currents, which has caused them to gather in masses to form large islands in different oceans, some of these garbage islands can reach up to 3 times the territory of Spain.
Garbage occupies large areas that become toxic, infertile, and damage the flora and fauna, which corresponds to modify our customs to consume less, sustainably, reuse and finally recycle in a more efficient way.

\section{Drinking water}

Although $71 \%$ of the surface of the Earth is covered with water, only $0.02 \%$ is potable, and while the World Health Organization considers that human beings require 100 liters a day to live, between their consumption for drink and clean, in several countries we exceed that figure by far, to consume more than 450 liters per person per day (including residual gray and black water) [Valdemar].

In addition, our goods also consume water, to be able to be manufactured industry, due to the necessary processes to manufacture many items and its components require this liquid, in the case of a denim trousers 7 thousand liters of water were required, while to build a car, 400,000 liters are needed. Additional to the treatment given to residual waste.

However, the agricultural sector is the largest consumer of water on the planet, using approximately $70 \%$ of the fresh water, plus the effects on water bodies by leaks or spills of pesticides, fertilizers, fungicides, herbicides and fertilizers used to maintain their performance.

Water is considered the "universal solvent", given its molecular structure, water has great capacity to establish hydrogen bonds with other molecules.

Because of this, it can dilute a large number of substances, water can be contaminated with inorganic substances, such as detergents and metals, natural or synthetic organic, all kinds of industrial waste, as well as biological waste, such as bacteria and pathogenic viruses.

Finally, a body of water can also be contaminated by acoustic or thermodynamic effects, affecting the ecological balance of the system, and consequently the biodiversity. 
Air

Also referenced as an atmosphere, it is a mass of gases that surrounds our planet, in ideal conditions for us, composed of nitrogen $(78 \%)$ and oxygen $(20.9 \%)$, with the presence of $0.95 \%$ of other inert gases and $0.03 \%$ of carbon dioxide, this mixture is not uniform, it depends on the height above sea level, temperature, humidity and some other factors, mainly pollution.

We consider air pollution to any substance, introduced into the atmosphere that has a detrimental effect on living beings and the environment. Some pollutants are the result of organic chemistry, such as $\mathrm{CO}_{2}$ and methane. But according to WHO figures of deaths in 2016, 4.2 million deaths were directly due to air pollution. Nowadays it is considered that the air in many urban areas is already too toxic, affecting more than 3000 million individuals, again, a determining factor in this process of contamination is the industry, but not least the abuse of fossil fuels, overpopulation, etc. The main pollutants are:

\section{Particles (PM)}

PMs are a common representative indicator of air pollution. They affect more people than any other pollutant. The main components of PM are sulphates, nitrates, ammonia, sodium chloride, soot, mineral powders and water. They consist of a complex mixture of solid and liquid particles of organic and inorganic substances suspended in the air. While particles with a diameter of 10 micrometers or less can penetrate and lodge deep within the lungs, there are other particles even more harmful to health, which are those with a diameter of 2.5 micrometers or less. These can cross the pulmonary barrier and enter directly into the bloodstream. Chronic exposure to particles contributes to the risk of developing cardiovascular and respiratory diseases, as well as lung cancer.

\section{Ozone $\left(\mathrm{O}_{3}\right)$}

Ozone at ground level is one of the main components of smog. This is formed by the photochemical reaction of pollutants such as nitrogen oxides (NOx) and volatile organic compounds (VOC) both waste emitted by vehicles, solvents and industry.
The highest levels of ozone are recorded during periods of sunny weather. It can cause respiratory problems, asthma, and reduce lung function

\section{Nitrogen dioxide $\left(\mathrm{NO}_{2}\right)$}

The main source is nitrate aerosols, which are also an important part of PM2.5 and combustion processes in heating, power generation and engines. It causes symptoms of bronchitis in asthmatic children, and decreased development of lung function.

\section{Sulfur dioxide $\left(\mathrm{SO}_{2}\right)$}

It is a colorless gas with a pungent odor that is generated by the combustion of fossils (coal and oil). It can affect the respiratory system and pulmonary functions, and causes eye irritation. The inflammation of the respiratory system causes cough, mucous secretion and aggravation of asthma and chronic bronchitis; It also increases the propensity of people to contract respiratory system infections. In combination with water, $\mathrm{SO}_{2}$ is converted to sulfuric acid, which is the main component of acid rain that causes deforestation.

\section{Feeding}

Around 795 million people in the world do not have enough food to lead a healthy and active life. Every year the FSIN (Food Security Information Network) involves several world organizations with the objective of diagnosing the humanitarian crisis in nutrition issues, in 2018 it is reported that the number of people with high health risk levels due to malnutrition has reached 124 million in 51 countries (11 million more than the previous year).

Extreme poverty, deficient agricultural exploitation, wars, climate change and economic conflicts are some of the main factors that can double the mortality rates of any region due to extreme malnutrition.

\section{Temperature}

A common, but at the same time difficult to measure, form is the warming of the environment resulting from the use of heat sources, which individually may seem insignificant, but in their totality, they raise the global temperature. 
Among these are the radiant heat of the large concrete plates in the urban spots, the heat produced by motors, boilers, kitchens and even the smoker, of course the industrial processes, aircraft and projectile engines, etc.

\section{Biological risks}

In its daily activity, the human being is exposed to contact with a great diversity of other living beings and chemical elements, whether they belong to a region or activity or as a result of weather phenomena, we can be attacked by amebas, bacteria or viruses, and in In case of an extraordinary increase in the number of cases of an infectious disease, this may be considered an epidemic. Likewise, if the epidemic covers several nations or the majority of individuals in a region, it becomes classified as a pandemic.

Although we have advanced in the development of medicines and vaccines to counteract various diseases, they also adapt, evolve, or mutate, and new diseases arise. According to the International Federation of Red Cross and Red Crescent Societies, the current diseases with the greatest risk to humanity are: Cholera, Dengue, Ebola, Malaria, Measles, Meningitis, Yellow fever, HIV / AIDS and Tuberculosis.

By a wide margin, chickenpox is the disease that most affected humanity, not only because more than 300,000 million people have died from it, but the majority who suffered it are left with skin marks for life, for the references found, it is considered that it has been present since 12000 BC. Figure 3 shows a list of the five diseases that have decimated humanity the most throughout history.

Finally it is worth mentioning that not all evolutionary changes always favor us, as a rule we consider as evolution the survival of the strongest (or the fittest), however this rule we stopped fulfilling it some time ago, because now we have many amenities and resources to extend the life of a person that natural selection seems to have designated it not to be achieved, so survival could depend on social or economic factors, resulting in an impoverishment of our genetic material.

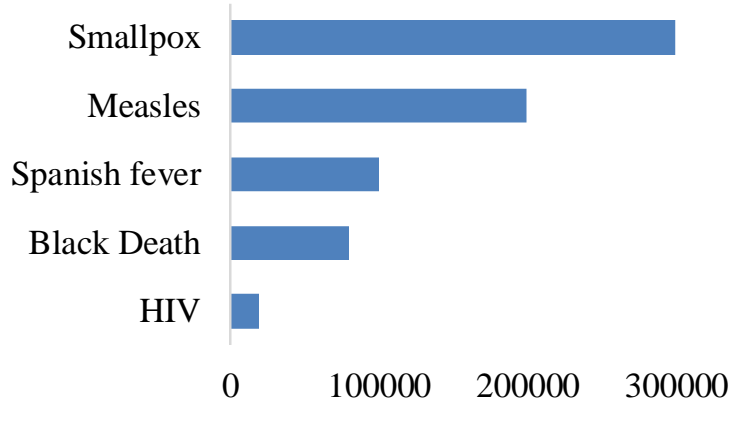

Figure 3 Main deadly diseases throughout history

\section{Face the facts}

Despite all this evidence, there are voices that still deny these effects, even some of the countries that pollute the most close their eyes and refuse to accept this reality, probably in an effort to avoid taking responsibility. In addition to that taking remedial measures would affect the income of some groups in power.

Most of us settle for commenting our concerns in social networks, which is the same as doing nothing, we have not really taken conscience of our environment, probably hoping that by government decree the contamination is eliminated, but without wanting to see us personally involved or affected.

Some steps have already been taken, we have technologies that have been maturing in the sense of efficiency and profitability. Recycling, water and air purification, biofuels, alternative energies and many more.

\section{Conclusion}

We can only speculate about whether there is still time to correct the course and alter our lifestyles for one with more common sense, conscious and sustained, that although it is difficult for the world to recover, at least slow down the rate at which we are destroying it.

Diversify our fuels, use sustainable energy sources, modify our culture of consumption and waste, stop thinking about individual interests and become citizens of the world, stop coveting so much wealth, for the common good, things that in theory may sound easy, but they involve a great challenge, simply, the day will come when we no longer have the opportunity to react. 
Going into space to colonize other planets sounds like a great adventure, but how many hundreds of years are needed and how many could have enough purchasing power to save themselves. The destiny of humanity is on afford in view of the present horizont this Earth, our house.

\section{References}

Campillo, S. (2014, 10 octubre). Las 10 pandemias más letales en la historia de la humanidad. Recuperado 21 abril, 2019, de https://hipertextual.com/2014/10/pandemias

Composición y propiedades del aire. (2014, 18 mayo). Recuperado 20 abril, 2019, de https://quimicayalgomas.com/quimicageneral/composicion-y-propiedades-del-aire/

Del Real, J. (2018, 20 febrero). ¿Cuánta basura generas al año? Recuperado 20 abril, 2019, de https://www.expoknews.com/cuanta-basurageneras-al-ano/

IFRC. (s.f.). Peligros biológicos: epidemias IFRC. Recuperado 21 abril, 2019, de https://www.ifrc.org/es/introduccion/disastermanagement/sobre-desastres/definicion--depeligro/tipologia-del-peligro/

Fondo para la Comunicación y la Educación Ambienta. (s.f.). Contaminación del agua. Recuperado 20 abril, 2019, de https://agua.org.mx/contaminacion-del-agua/

Food Security Information Network. (2018). Global Report Food Crisis 2018. Recuperado de https://www.wfp.org/content/global-reportfood-crises-2018.pdf

Ionkova, K. (2018, 31 agosto). What a Waste 2.0: A Global Snapshot of Solid Waste

Management to 2050. Recuperado 20 abril, 2019, de https://openknowledge.worldbank.org/handle/ 10986/30317

NatGeo. (2010, 5 septiembre). La contaminación del aire. Recuperado 20 abril, 2019 , de https://www.nationalgeographic.es/medioambiente/la-contaminacion-del-aire
Organización Mundial de la Salud. (2018, 2 mayo). Calidad del aire y salud. Recuperado 20 abril, 2019, de https://www.who.int/es/news-room/factsheets/detail/ambient-(outdoor)-air-qualityand-health

Sostenibilidad.com. (s.f.). Islas de basura en los océanos. Recuperado 20 abril, 2019, de https://www.sostenibilidad.com/agua/islas-debasura/

The World Bank. (2019, 1 abril). Solid Waste Management. Recuperado 20 abril, 2019, de http://www.worldbank.org/en/topic/urbandevel opment/brief/solid-waste-management

Valdemar, J. (2017, 3 agosto). México, el quinto país que más consume agua. Recuperado 20 abril, 2019, de https://www.elfinanciero.com.mx/economia/me xico-el-quinto-pais-que-mas-consume-agua 